\title{
Cyclic testing of single bay confined masonry walls with various connection details
}

Matošević, Đurđica; Sigmund, Vladimir; Guljaš, Ivica

Source / Izvornik: Bulletin of Earthquake Engineering, 2015, 13, 565 - 586

Journal article, Published version

Rad u časopisu, Objavljena verzija rada (izdavačev PDF)

https://doi.org/10.1007/s10518-014-9627-8

Permanent link / Trajna poveznica: https:/urn.nsk.hr/urn:nbn:hr:133:241520

Rights / Prava: Attribution 4.0 International/Imenovanje 4.0 međunarodna

Download date / Datum preuzimanja: 2023-04-26

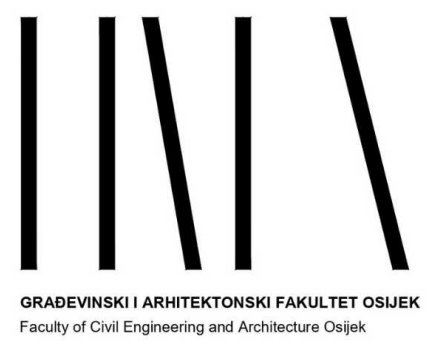

Repository / Repozitorij:

Repository GrAFOS - Repository of Faculty of Civil Engineering and Architecture Osijek
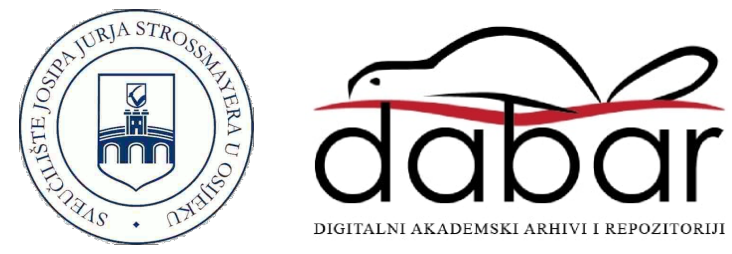


\title{
Cyclic testing of single bay confined masonry walls with various connection details
}

\author{
Durđica Matošević • Vladimir Sigmund • Ivica Guljaš
}

Received: 20 November 2013 / Accepted: 18 April 2014 / Published online: 13 May 2014

C) Springer Science+Business Media Dordrecht 2014

\begin{abstract}
The test results of nine confined masonry wall specimens, with three different connection details between the masonry and the tie-columns and one unreinforced masonry wall, are presented. The specimens were executed and were tested under constant vertical and cyclic lateral loads. Failure modes, hysteresis loops, resistance envelope curves, averaged evaluated bilinear response envelope curves and behaviour factors were all obtained. Confinement brought an increase in the stiffness, lateral load capacity, ductility and hysteretic energy dissipation of the walls. The connection details did not influence the initial stiffness or the maximum lateral resistance, but they did improve the nonlinear wall behaviour, behaviour factors and hysteretic energy dissipation. They also helped in activating the whole wall for lateral load resistance and maintained its composite behaviour well into the nonlinear range. The measured behaviour factors of all the specimens were above the values suggested by the Eurocodes. The analytical expressions available differed from the prediction quality of the measured results.
\end{abstract}

Keywords Confined masonry · Masonry-tie connection · Behaviour factor · Lateral resistance

\section{Introduction}

Confined masonry consists of a masonry wall and vertical (tie-columns) and horizontal (tiebeams) constituents that act as confining elements built on all four sides of the masonry wall panel. Masonry walls together with reinforced concrete tie-columns transmit the gravity load from the slab(s) above down to the foundation. Confining elements improve the stability and integrity of masonry walls for in-plane and out of plane earthquake effects (Meli and Brzev 2011). The confined masonry system has generally evolved empirically, by trial and

Đ. Matošević · V. Sigmund $(\varangle) \cdot$ I.Guljaš

Faculty of Civil Engineering, J.J.Strossmayer University of Osijek,

31000 Osijek, Croatia

e-mail: sigmund@gfos.hr 
error, and much information regarding its seismic behaviour is still lacking. Despite the code's development, the vast majority of confined masonry construction takes place in a non-engineered fashion, according to historical local construction practice.(World Housing Encyclopedia 2011).

In Eurocode 6 and Eurocode 8, the beneficial effect of confining elements is taken into account implicitly by increasing the value of the structural behaviour factor $(q)$. Vertical tie-columns can be taken into account when they are properly connected to a masonry wall, by a "toothed" or dowel connection. However, their contribution and the distinction between these two connections have only been described generally. Eurocodes do not accept the contribution of confinement to the out of plane resistance of walls.

Good bonding between a masonry wall and adjacent reinforced concrete tie-columns is important for satisfactory earthquake performance and for delaying undesirable cracking and separation at the wall-to-tie-column interface. Codified connection methods cause problems during construction, and it is a common practice, at least in Eastern Europe, to try to avoid them. There is little experimental evidence concerning the interlocking details and their influence is hard to quantify. In a UNIDO/UNDP (1984) study, toothed connections were found to be beneficial to wall performance. Another limited study was performed by San Bartolome et al. (2004) that compared confined masonry walls with toothed and dowel connections. Both connection details were found to improve a wall's lateral performance. However, the study does not conclusively recommend the connection type.

Therefore, we have carried out additional research focused specifically on different tiecolumns - masonry wall connection details in which we have tried to evaluate and quantify the influence of the connection scheme. The influence of three different types of connection details between the masonry panel and reinforced concrete tie-columns on the resistance and displacement capacity of confined masonry walls has been studied for a series of specimens, built at a scale of 1:1.5 and proportioned as bending elements with significant tension and compression stresses at the wall-ends when exposed to a combination of vertical and in-plane lateral loads. The behaviour of confined panels with a smooth connection at the masonryconcrete interface, a smooth connection with the steel dowels in the bed joints and traditional tooth-type joints, were compared to the behaviour of a control unreinforced masonry wall with the same dimensions. The results indicated that the presence of the ties, even if there was no connection between ties and the wall, significantly improved the wall behaviour and satisfied the minimum code requirements. Specimens without the connection failed due to diagonal compression failure in a brittle manner with a higher scatter of results. The presence of the connection improved the nonlinear behaviour of the specimens.

\section{Prototype and model specimens}

The prototype represented a middle wall in a residential low-rise confined masonry building with a $25 \mathrm{~m}^{2}$ attributed floor area $\mathrm{A}_{\mathrm{w}} / \Sigma \mathrm{A}_{\mathrm{fl}}=2.5 \%$ (Fig. 1). The ribbed slabs were $21 \mathrm{~cm}$ thick ( $16 \mathrm{~cm}$ ribs spaced at $40 \mathrm{~cm}$ with a $5 \mathrm{~cm}$ topping slab) and the wall was $216 \mathrm{~cm}$ long, $249 \mathrm{~cm}$ high and $29 \mathrm{~cm}$ thick. Reinforced-concrete ties at the wall-ends were $\mathrm{b} / \mathrm{h}=29 / 21 \mathrm{~cm}$. The wall was designed according to the current European guidelines (EN 1996-1-1 2005; EN 1998-1 2004).

The total design vertical loading - from the floors above-on the prototype wall at the basement was:

$$
N_{s d}=\Sigma G_{k, j}+\psi_{2 i} \cdot \varphi \cdot Q_{k, i}=300 \mathrm{kN}
$$



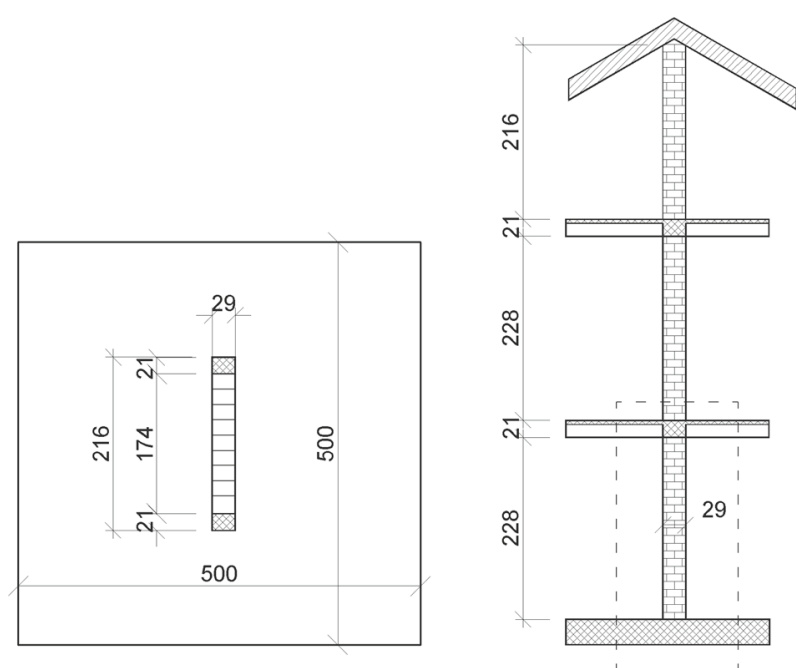

Fig. 1 Prototype wall (in $\mathrm{cm}$ )

which produced a vertical axial stress of

$$
\sigma_{0}=N_{S d} / A_{\text {wall }}=0.48 \mathrm{MPa} \text { and an axial force ratio of } 0.48 / 2.16 \times 100=22 \% .
$$

A ground floor wall of the prototype was chosen to be modelled and tested under a constant vertical and cyclic in-plane lateral load. Ten, one-storey, one-bay, masonry wall specimens were modelled at a scale of 1:1.5 according to the complete similarity rules (Harris and Sabnis 1999). Specimens maintained complete similarity, implying that the prototype and the model had the same material properties. Nine specimens were produced as confined masonry consisting of the wall built on the foundation beam and the horizontal and vertical reinforced concrete confining elements (ties) built on the remaining three sides of the masonry wall panel. The masonry wall was constructed first, followed by the cast in-place reinforcedconcrete tie-columns and the reinforced-concrete tie-beam constructed on top of the wall. The reinforcement of the ties was carried out in a frame manner. One specimen was produced as an unreinforced masonry wall with the beam at the top.

The specimens' dimensions, details and reinforcement are presented in Fig. 2 and Table 1. They were divided into three groups of three specimens for the statistical evaluation of the results. Group A had three confined masonry wall specimens, without any connections between the masonry and the tie-columns. Group B had three confined masonry wall specimens, with a toothed connection between the masonry and tie-columns, and the three specimens in Group $\mathrm{C}$ had a confined masonry wall with U-shaped dowels, for a connection between the masonry wall and the tie-columns. Group D was an unreinforced masonry wall.

\section{Geometry and material properties}

The specimens were built using standard local materials, as used in Croatia: perforated clay masonry units V-5 that belong to Group 2 under Eurocode 6 with the dimensions b/h/t = $25 / 19 / 19(\mathrm{~cm})$, a nominal compressive strength of $15 \mathrm{MPa}$, and a volume weight of $7.9 \mathrm{kN} / \mathrm{m}^{3}$ (Matosević et al. 2009). The concrete used in the ties was C30/37 and the reinforcement was 


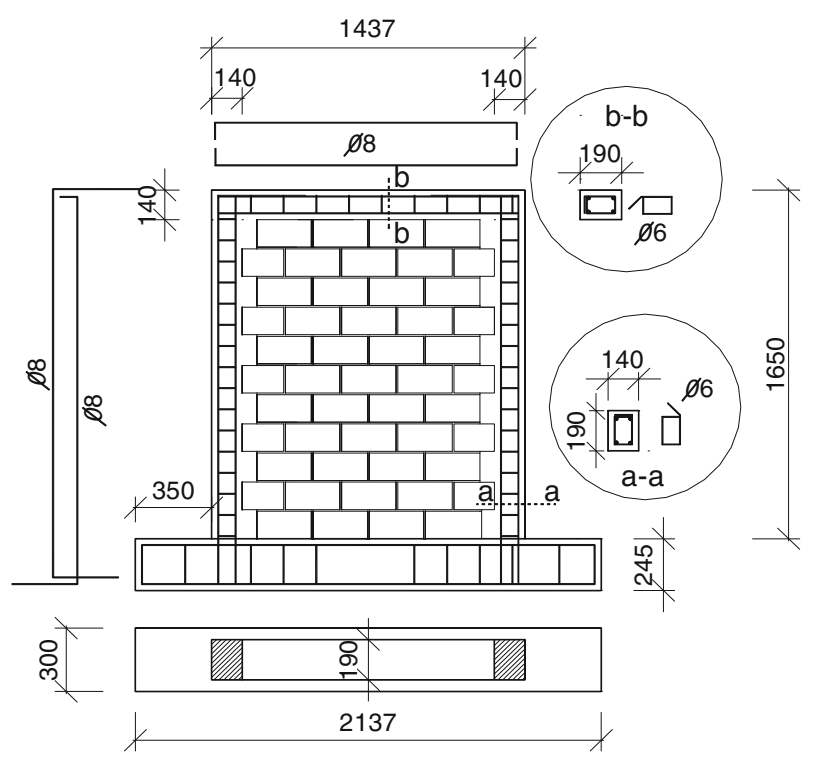

Fig. 2 Tested model specimens

B500B. The general purpose mortar was made in situ in volume proportions cement: hydrated lime: sand $=1: 1: 5$. The mechanical properties of the concrete, reinforcement, masonry units, mortar and masonry wallets were tested according to the European norms, and are presented in Table 2.

The tie-columns were reinforced with a longitudinal reinforcement of $4 \phi 8 \mathrm{~mm}$ anchored to the foundation beam and with closed stirrups of $\phi 6 \mathrm{~mm}$ spaced at $10 \mathrm{~cm}$. The horizontal tie-beams were reinforced by $4 \phi 8 \mathrm{~mm}$ with stirrups of $\phi 6 \mathrm{~mm}$ spaced at $14 \mathrm{~cm}$. A toothed connection, in the Group B specimens, was performed in the manner prescribed by the EC6 (Fig. 3). Anchoring between the masonry wall and tie-columns in the Group $\mathrm{C}$ specimens was provided by $\phi 6 \mathrm{~mm}$ dowel stirrups anchored in every bed joint (Fig. 3).

Masonry units were cut from the original ones, preserving the number and area of the holes, with an equal number of bed joints in both the prototype and the models. Their dimensions were $b / h^{*} / t=25 / 13 / 19 \mathrm{~cm}$ (where $b, h^{*}$ and $t$ are the length, height and width of the unit, respectively). All the specimens were produced under the same circumstances and by the same craftsman in three consecutive groups: A1, B1 and C1 then A2, B2 and C2 and finally A3, B3, C3 and D.

\section{Test setup}

The test setup consisted of a closed steel testing frame connected to the strong floor and horizontally supported with braces, as shown in Fig. 4a, b. The specimen's foundation beam was fixed to the steel frame and the strong floor. The possibility of its sliding along the beam was further prevented by restraints. Four hydraulic actuators were fixed to the frame in order to simulate constant vertical and in-plane lateral loadings. The vertical load, which simulated loading from the upper floors, was applied to the reinforced concrete beam and placed on the horizontal tie over a thin Teflon layer in order to evenly distribute the pressure 
Table 1 Specimen groups

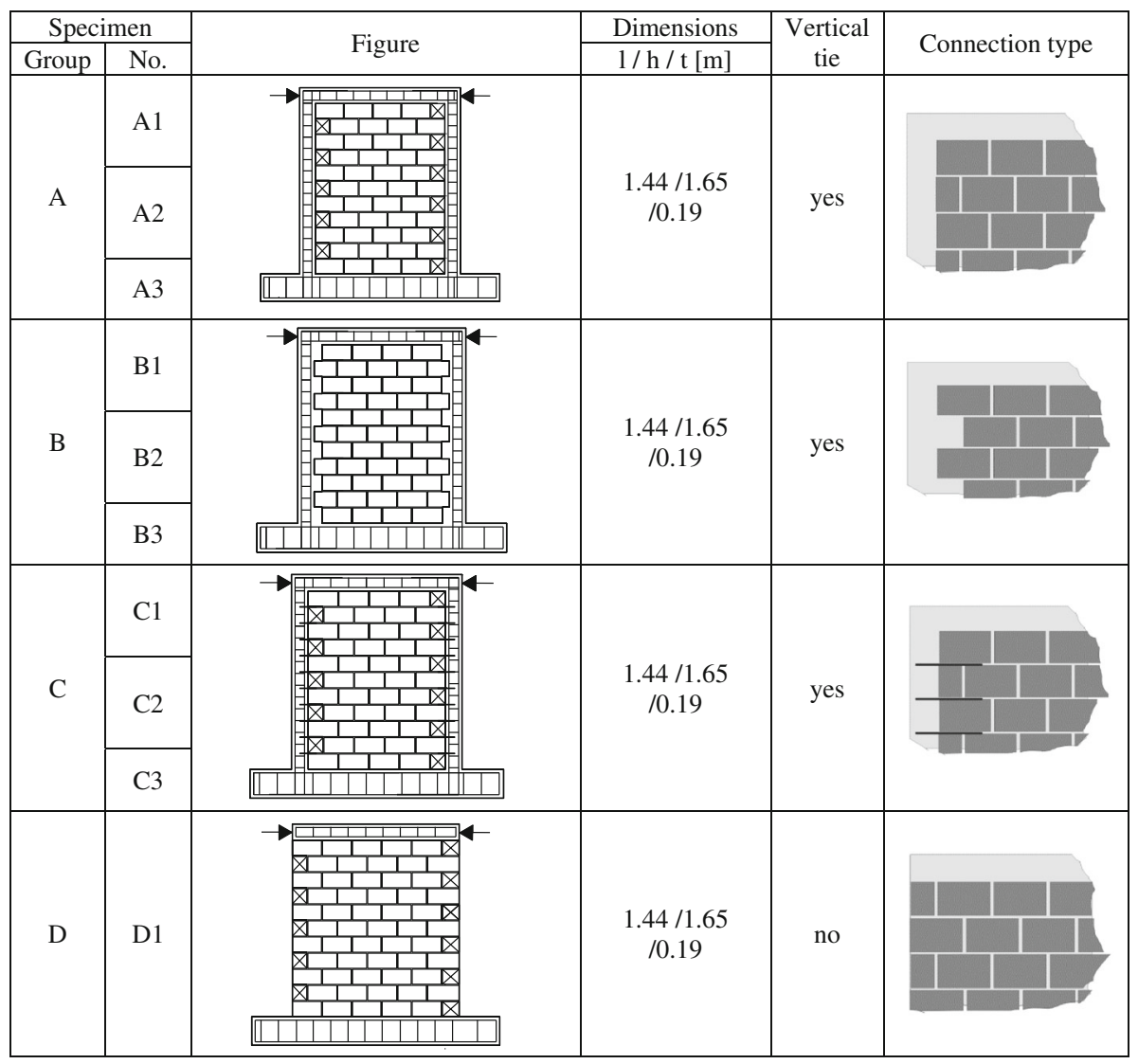

over the entire wall. Vertical actuators were placed on a carriage wheel that enabled them to move horizontally and prevented their rotation. The vertical load was kept almost constant at $133 \mathrm{kN}$, by means of special pressure valves. The lateral load was applied cyclically to the specimen's tie-beam ends by double-acting hydraulic jacks with a $350 \mathrm{kN}$ capacity. Cyclic lateral loading was increased in steps of $10 \mathrm{kN}$. Overall testing was performed as force (at the initial stage) and controlled displacement (at the later stages), after the maximum lateral load was reached and the system stiffness degraded) (Fig. 6). When the masonry wall was extensively damaged, lateral loading was applied from one side only, until the lateral load fell to under $80 \%$ of the maximum value and/or the wall experienced heavy damage.

The following experimental results were continually recorded: applied loads at each of the four loading points by load cells; vertical and horizontal displacements of the specimen at the beam-ends by LVDTs; foundation beam movement by LVDTs; the elongation of diagonals (on the frame) by string transducers; and local strains at the frame's critical points (columnand beam-ends) by strain gages (Fig. 5). Displacement transducers for global deformations were placed on separate scaffoldings so that absolute displacements were measured. For signal conditioning, data acquisition and analysis, two Dewe 30-16 systems with the DEWEsoft ver. 6.6.7 software and a $1 / 100 \mathrm{~s}$ data sampling rate were used. The formation of the first 
Table 2 Material properties

\begin{tabular}{|c|c|c|c|c|c|c|}
\hline \multicolumn{2}{|l|}{ Material } & Property description & Symbol & Value & SD & Units \\
\hline \multirow{2}{*}{\multicolumn{2}{|c|}{$\begin{array}{l}\text { Clay hollow masonry } \\
\text { units }\end{array}$}} & \multirow{2}{*}{$\begin{array}{l}\text { Normalized vertical } \\
\text { compressive strength } \\
\text { Normalized horizontal } \\
\text { compressive strength }\end{array}$} & $\mathrm{f}_{\mathrm{b}}$ & 17.0 & \multirow[t]{5}{*}{$\mathrm{COV}=15.1$} & \multirow[t]{2}{*}{$\mathrm{MPa}$} \\
\hline & & & $\mathrm{f}_{\mathrm{bh}}$ & 2.6 & & \\
\hline \multirow[t]{13}{*}{ Mortar } & A1 & \multirow{13}{*}{$\begin{array}{l}\text { Compressive strength/ } \\
\text { bending-tensile strength }\end{array}$} & \multirow[t]{13}{*}{$\mathrm{f}_{\mathrm{m}} / \mathrm{f}_{\mathrm{mt}}$} & $6.11 / 1.26$ & & \multirow[t]{13}{*}{$\mathrm{MPa}$} \\
\hline & $\mathrm{A} 2$ & & & $5.57 / 1.12$ & & \\
\hline & A3 & & & $6.43 / 1.14$ & & \\
\hline & Aavg & & & $6.04 / 1.17$ & \multirow[t]{4}{*}{$0.43 / 0.08$} & \\
\hline & B1 & & & $6.64 / 1.58$ & & \\
\hline & B2 & & & $5.94 / 1.23$ & & \\
\hline & B3 & & & $5.86 / 1.15$ & & \\
\hline & Bavg & & & $6.15 / 1.32$ & \multirow[t]{4}{*}{$0.43 / 0.23$} & \\
\hline & $\mathrm{C} 1$ & & & $7.17 / 1.83$ & & \\
\hline & $\mathrm{C} 2$ & & & $5.06 / 1.07$ & & \\
\hline & C3 & & & $5.86 / 1.15$ & & \\
\hline & Cavg & & & $6.03 / 0.42$ & $1.07 / 0.42$ & \\
\hline & $\mathrm{D}$ & & & $5.89 / 1.26$ & - & \\
\hline \multirow{6}{*}{\multicolumn{2}{|c|}{ Masonry wall }} & $\begin{array}{l}\text { Mean/characteristic } \\
\text { compressive strength }\end{array}$ & $\mathrm{f}_{\mathrm{k}}$ & $2.6 / 2.2$ & & $\mathrm{MPa}$ \\
\hline & & $\begin{array}{l}\text { Characteristic tensile } \\
\text { strength }\end{array}$ & $\mathrm{f}_{\mathrm{t}}$ & 0.22 & & $\mathrm{MPa}$ \\
\hline & & Elastic modulus & $\mathrm{E}$ & 3,900 & & $\mathrm{MPa}$ \\
\hline & & Ultimate strain & $\varepsilon_{\mathrm{u}}$ & 0.57 & & $\%$ \\
\hline & & $\begin{array}{l}\text { Characteristic initial } \\
\text { shear strength }\end{array}$ & $\mathrm{f}_{\mathrm{vk} 0}$ & 0.44 & & $\mathrm{MPa}$ \\
\hline & & $\begin{array}{l}\text { Characteristic friction } \\
\text { coefficient }\end{array}$ & $\mu$ & 0.291 & & - \\
\hline \multirow[t]{4}{*}{ Concrete } & $\mathrm{A} 1, \mathrm{~B} 1, \mathrm{C} 1$ & \multirow{4}{*}{$\begin{array}{l}\text { Characteristic compressive } \\
\text { strength of the concrete } \\
\text { cubes }\end{array}$} & \multirow[t]{4}{*}{$\mathrm{f}_{\mathrm{ck}, \text { cube }}$} & 43.8 & & \multirow[t]{4}{*}{$\mathrm{N} / \mathrm{mm}^{2}$} \\
\hline & $\mathrm{A} 2, \mathrm{~B} 2, \mathrm{C} 2$ & & & 38.0 & & \\
\hline & A3;B3,C3 & & & 28.6 & & \\
\hline & A-Cavg & & & 36.8 & 7.67 & \\
\hline \multirow{3}{*}{\multicolumn{2}{|c|}{$\begin{array}{l}\text { Longitudinal and } \\
\text { transversal } \\
\text { reinforcement }\end{array}$}} & Characteristic yield strength & $\mathrm{f}_{\mathrm{yk}}$ & 594 & & $\mathrm{~N} / \mathrm{mm}^{2}$ \\
\hline & & $\begin{array}{l}\text { Characteristic } \\
\text { ultimate strength }\end{array}$ & $\mathrm{f}_{\mathrm{uk}}$ & 699 & & $\mathrm{~N} / \mathrm{mm}^{2}$ \\
\hline & & Elastic modulus & $\mathrm{E}_{\mathrm{S}}$ & 206,957 & & $\mathrm{~N} / \mathrm{mm}^{2}$ \\
\hline
\end{tabular}

and adjacent significant cracks in the masonry and all significant phenomena that occurred during testing were observed optically and registered photographically (masonry crushing, crack developments in the masonry and concrete, crack patterns).

\section{Test results}

We will present here the results obtained for the specimens and their dimensions. For every specimen, cyclic experimental response curves (hysteresis curves) were determined from which the primary curves (resistance envelope) for the cyclic lateral loading were obtained. 
Fig. 3 Connection details for toothed $($ GroupB) and dowel connection $($ Group $C)$ types (all dimensions are in $\mathrm{mm}$ )

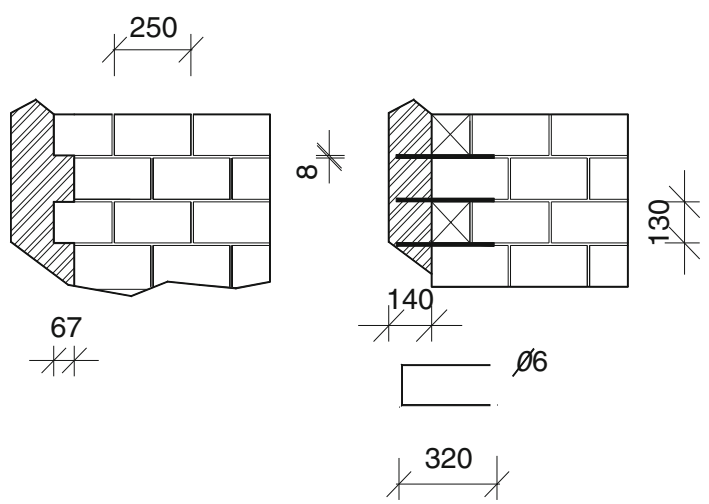

In order to be able to accurately simulate the structural performance of the confined masonry in a nonlinear response history analysis, it was necessary to estimate the stiffness, strength and deformation characteristics of the system. The bilinear idealization of the measured resistance envelope curve was also estimated.

\subsection{Collapse mechanisms}

All the confined masonry specimens failed in shear, although they had a favourable $\mathrm{h} / \mathrm{l}$ ratio and satisfied the ideal criteria for the flexural failure. They had higher reinforced tie-columns and high axial load. The formation and development of inclined diagonal cracks followed the path of the bed and head-joints (stepped) or else went through the bricks. During testing on all the specimens, deterioration occurred in the following sequence:

- Initial masonry cracks occurred at the wall's mid-height;

- A network of diagonally-oriented cracks appeared and continually increased in number;

- Sporadic spalling of the masonry outer shells was observed;

- The cracks propagated to the vertical ties;

- The wall collapsed.

Typical final crack patterns for every specimen group are presented in Fig. 7 and are described in detail in Table 3. The crack propagation from the wall to the tie-column depended on the connection type. Diagonal cracks were dominant for all the specimen groups and crushing of the masonry units at the wall corners was not observed. Five damage levels were distinguished, according to the EMS-98 scale (Grünthal 1998), and corresponding damage grades were adopted: Grade 1: Slight damage; Grade 2: Moderate damage; Grade 3: Heavy damage; Grade 4: Very heavy damage and Grade 5: Destruction.

In the specimens of Group B and Group C, cracks propagated from the wall into the tie-columns, indicating their composite shear failure. In the Group A specimens, horizontal cracks appeared at the outer edges of the tie-columns, indicating their tensile failure. With drift increase, the number and depth of the cracks increased with the spalling of the outer shells of the masonry units. The Group A specimens had few bigger diagonal cracks with the diagonal collapse shear failure of the wall. The Group B and C specimens had more cracks spread over the wall with a mixture of diagonal shear and in-plane moment failure collapse mechanisms with predominant shear that should be used as the basis for the design of confined masonry walls at small drifts. 


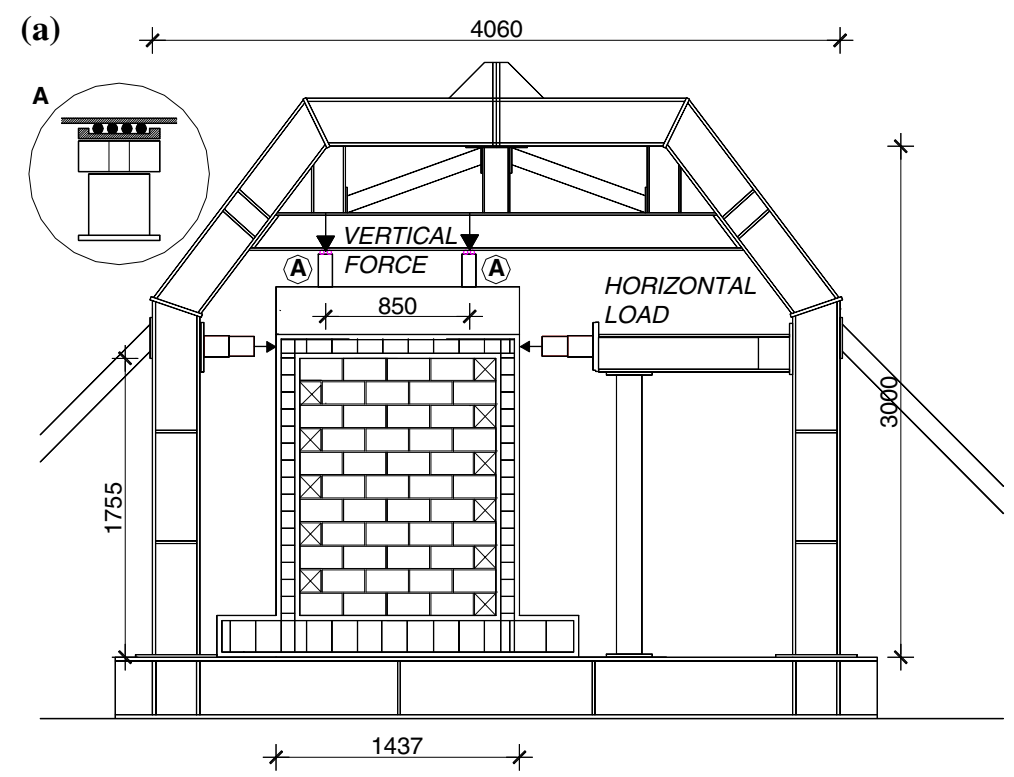

(b)

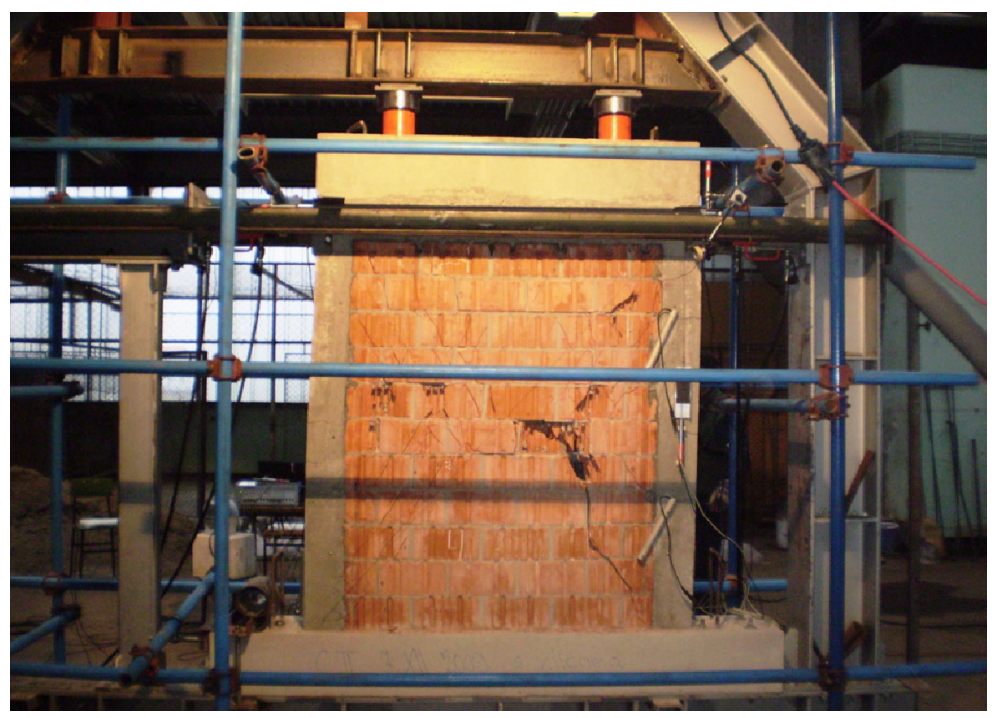

Fig. 4 a Test setup. b Photograph of the test setup

\subsection{Hysteresis loops and resistance envelope curves}

For all the specimens, experimental response curves (hysteresis loops) of the first and second loading cycles (Fig. 8) were determined. There was no significant difference between the two loading cycles, up to drifts of about $0.3 \%$ for the specimens in Groups A, B and C. Specimen $\mathrm{D}$ behaved in the same manner up to a drift of $0.15 \%$ with lower stiffness. Deterioration of the basic and post-capping strength and unloading stiffness were observed afterwards and 
Fig. 5 Measuring equipment
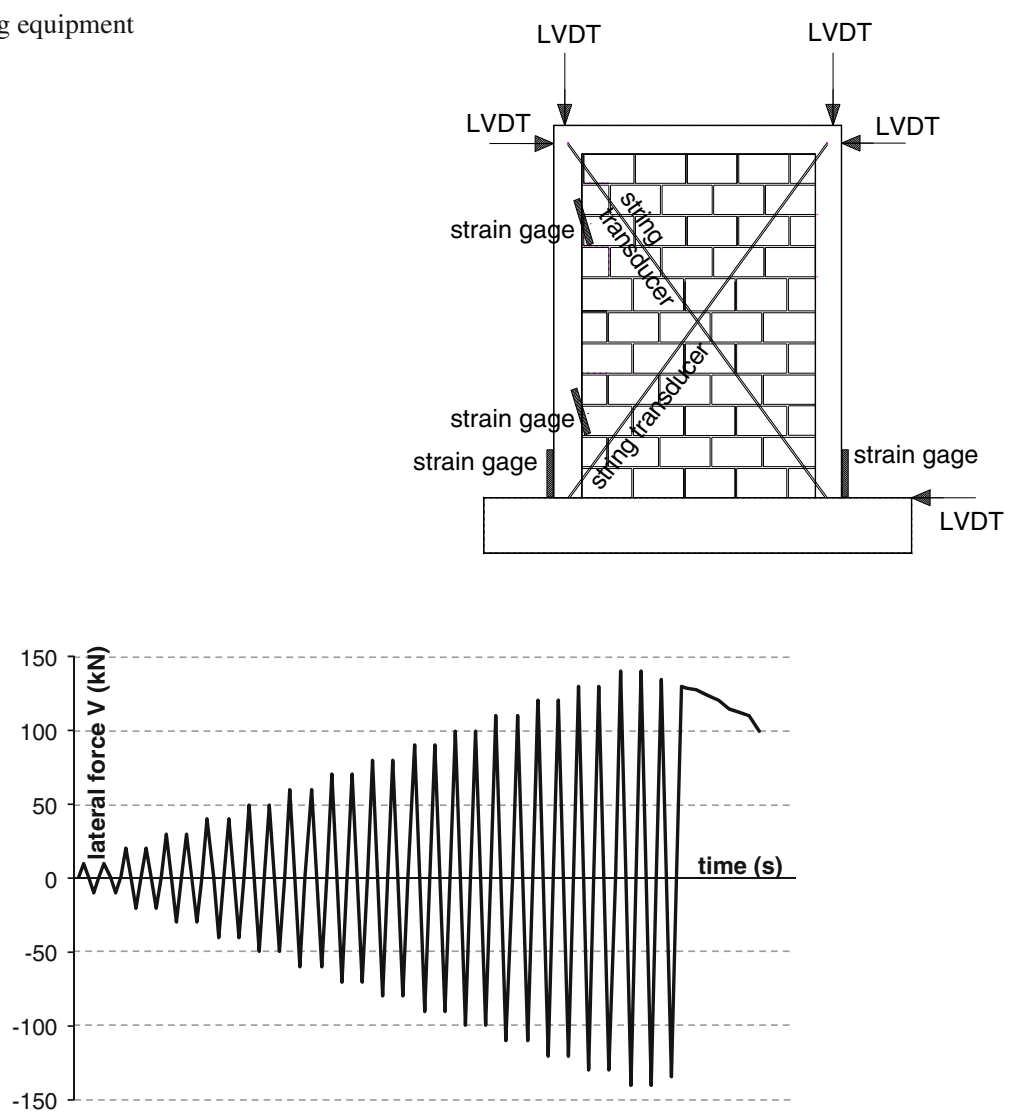

Fig. 6 Cyclic lateral loading time history
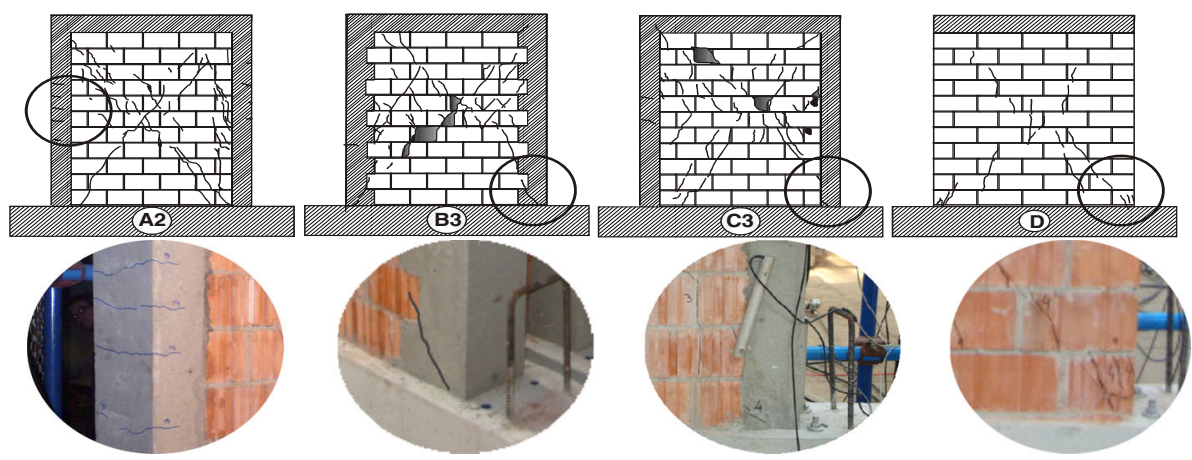

Fig. 7 Damage pattern and cracking details

systems exhibited accelerated reloading stiffness deterioration. The strength attained at the second loading cycle was always smaller than in the first one. 


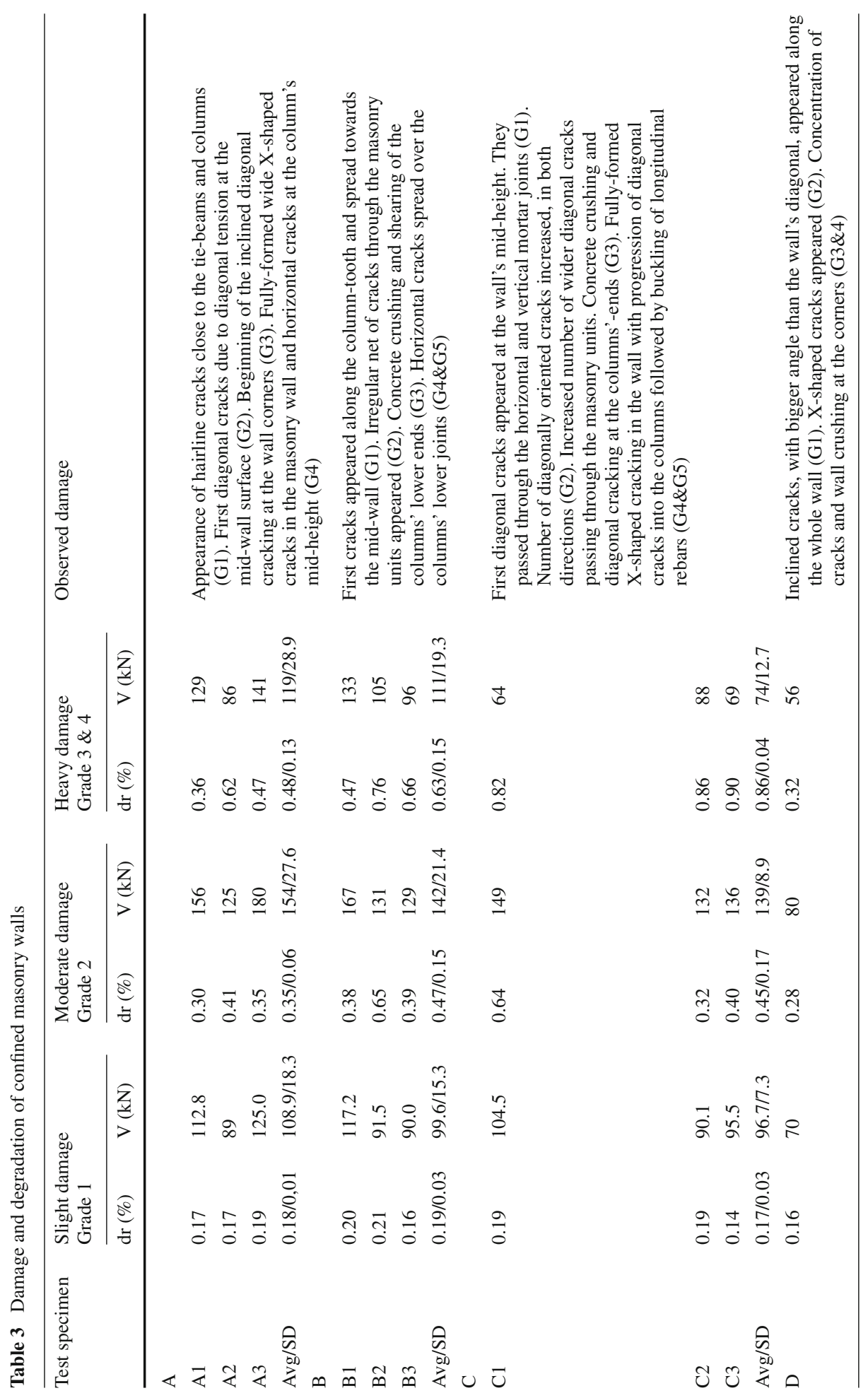



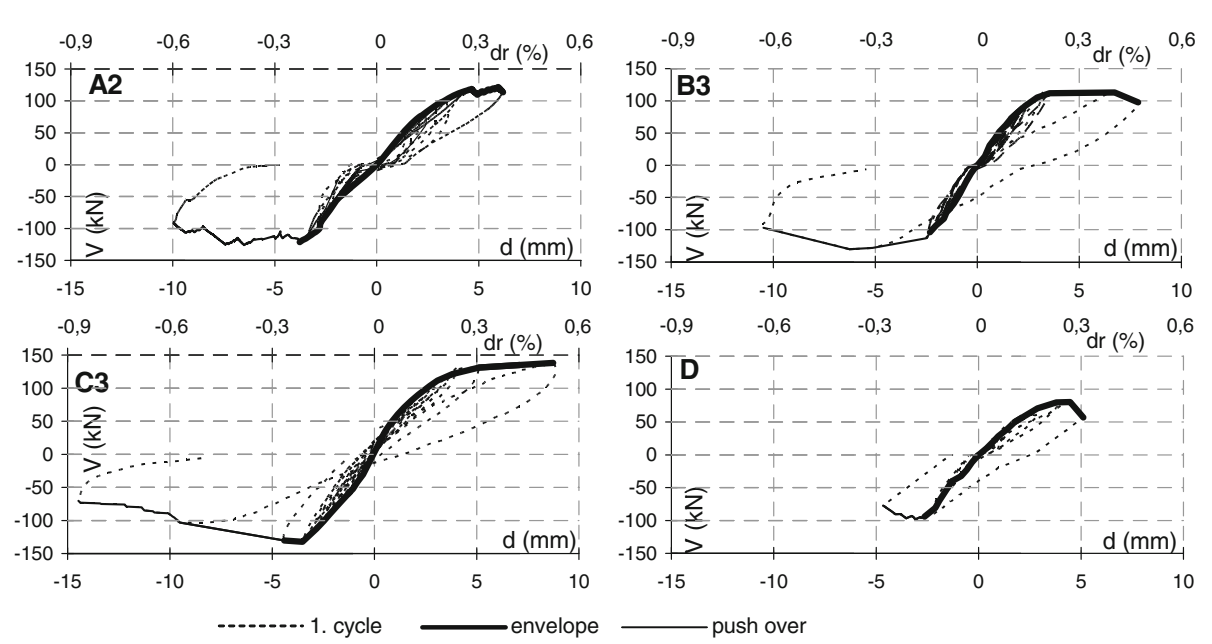

Fig. 8 Hysteresis loops and resistance envelope curves of four specimens

The resistance envelope curve was formed by connecting the peak points in the first loading cycles under increasing deformations and a monotonic push-over test. Displacement based push-over protruded further into the nonlinear range until the point at which the specimens experienced very heavy damage (damage Grade 4). That point depended on the connection type. It occurred at average drifts of $0.5,0.6,0.9$ and $0.3 \%$ for the specimens in Groups $\mathrm{A}$, $\mathrm{B}, \mathrm{C}$ and D, respectively. The hysteresis loops of the specimens in Groups A, B and C were similar. Pinching hysteretic behaviour (less pronounced in Group C) was observed in all the specimens with post-capping strength deterioration. After the opening of the first large cracks, the load resistance of the Group A specimens degraded quickly and significantly, while the Group B and C specimens were able to take up new load cycles. Specimen D behaved in a brittle manner. Soon after the maximum resistance was reached (at a drift of $0.28 \%$ ), it began to lose its strength and collapsed at a drift of $0.32 \%$.

Current design practices are based on the assumption that a large energy dissipation capacity is necessary to mitigate the effects induced by earthquakes. This assumption has very often led to the notion that a good structural system should be characterized by 'fat' hysteresis loops. Based on the results of Fig. 8, it can be concluded that, among the four groups of specimens, the $\mathrm{B}$ and $\mathrm{C}$ specimens produced the best loop. Their detailed connections fulfilled the requirements of ductility and energy dissipation. They responded well beyond the elastic limit and developed a mechanism involving a ductile inelastic response in the beam-column joints.

The cumulative input energy $E_{a}$ (calculated as the area under the positive part of the resistance envelope curve) and hysteretic energy dissipation $E_{d}$ (calculated as the area of all hysteretic loops up to a certain drift) for given drift ratios are presented in Fig. 9. While the amount of the input energy was similar for specimens A, B and C, the amount of the dissipated hysteretic energy depended on the connection type. It was higher in the specimens with connections (B and C) than in the specimens without connections (A), and specimen D.

\subsection{Bilinear idealization of the resistance envelope curve}

The measured resistance envelope curve (primary curve) of all the specimens was simplified by a bilinear curve. For each specimen, two loading and unloading cycles were monitored, 

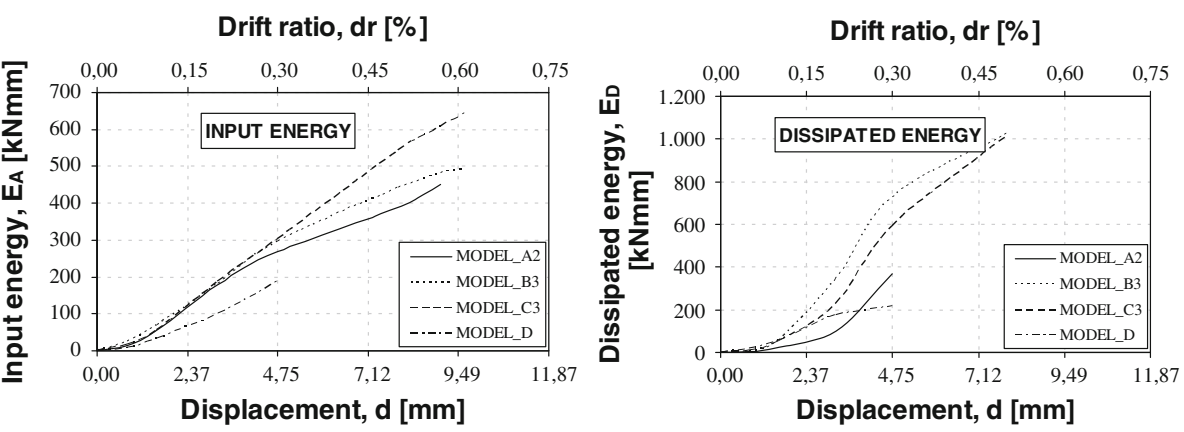

Fig. 9 Cumulative input and dissipated energy
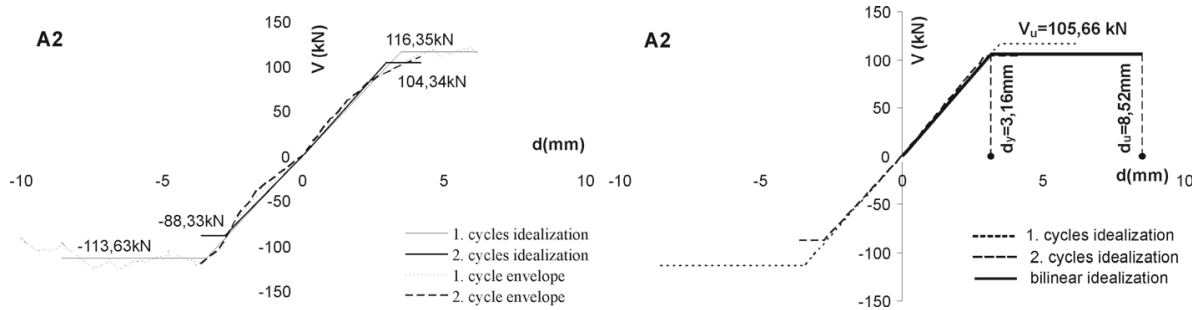

Fig. 10 Bilinear idealization of the resistance envelope curves for Specimen A2

and two positive and two negative envelope curves were obtained. The elastic stiffness, $K_{e l}$, was evaluated by Frumento et al. (2009) as a secant of the experimental resistance envelope curve at the base-shear value of $0.7 \cdot V_{\max }$.

$$
K_{e l}=\frac{V_{c r}}{d_{c r}} \text { where } V_{c r}=0.7 \cdot V_{\max }
$$

In order to determine one bilinear curve for each specimen, the elastic displacement $d_{y}$ and the maximum value of the horizontal force of the bilinear curve were defined as an average of the four values for each of the two positive and two negative cycles:

$$
\begin{aligned}
d_{y} & =\text { mean }\left(\left|d_{y 1}^{+}\right| ;\left|d_{y 2}^{+}\right| ;\left|d_{y 1}^{-}\right| ;\left|d_{y 2}^{-}\right|\right) \\
V_{U} & =\operatorname{mean}\left(\left|V_{U 1}^{+}\right| ;\left|V_{U 2}^{+}\right| ;\left|V_{U 1}^{-}\right| ;\left|V_{U 2}^{-}\right|\right) \\
d_{y} & =V_{U} / K_{e l}
\end{aligned}
$$

The ultimate displacement, $d_{u}$, of the wall corresponds to the largest of the displacements, at which the base shear decreased to $0.8 \cdot V_{\max }$. During testing, this was achieved in the push-over experimentation stage. The ultimate force, $V_{u}$, was evaluated by the equal energy dissipation capacity. The resistance envelope curve and its bilinear idealization for Specimen A2 are presented in Fig. 10. The characteristic values of the resistance envelope curves and the corresponding bilinear curves of all the tested specimens are given in Table 4. Both loading cycles-positive and negative-were considered in order to evaluate the maximum lateral force and its degradation.

The evaluated parameters of the bilinear envelope curves are presented in Table 4. The confined masonry wall elements (Groups A, B and C) remained elastic up to a drift of about $0.2 \%$, indicating that their elastic behaviour did not depend on the connection type. 
Table 4 Evaluated parameters of the experimental resistance envelopes' bilinear idealizations

\begin{tabular}{lcrrrlllllll}
\hline & $\begin{array}{l}\mathrm{K}_{\mathrm{el}} \\
(\mathrm{kN} / \mathrm{mm})\end{array}$ & $\mathrm{V}_{\mathrm{el}}$ & $\begin{array}{l}\mathrm{V}_{\max } \\
(\mathrm{kN})\end{array}$ & $\begin{array}{l}\mathrm{V}_{\mathrm{u}} \\
(\mathrm{kN})\end{array}$ & $\begin{array}{l}\mathrm{d}_{\mathrm{el}} \\
(\mathrm{mm})\end{array}$ & $\begin{array}{l}\mathrm{d}_{\mathrm{y}} \\
(\mathrm{mm})\end{array}$ & $\begin{array}{l}\mathrm{d}_{\mathrm{Vmax}} \\
(\mathrm{mm})\end{array}$ & $\begin{array}{l}\mathrm{d}_{\mathrm{u}} \\
(\mathrm{mm})\end{array}$ & $\begin{array}{l}\mathrm{d}_{\max } \\
(\mathrm{mm})\end{array}$ & $\begin{array}{l}\text { Crack } \\
\text { storey drift } \\
\mathrm{dr}_{\mathrm{e}}(\%)\end{array}$ & $\begin{array}{l}\text { Ultimate } \\
\text { storey drift } \\
\mathrm{dr}_{\mathrm{u}}(\%)\end{array}$ \\
\hline $\mathrm{A} 1$ & 41.2 & 112.3 & 161.1 & 155.9 & 2.76 & 3.82 & 4.80 & 5.70 & 5.70 & 0.17 & 0.36 \\
$\mathrm{~A} 2$ & 33.5 & 87.8 & 125.7 & 105.7 & 2.62 & 3.16 & 6.52 & 8.52 & 9.94 & 0.17 & 0.54 \\
$\mathrm{~A} 3$ & 39.1 & 125.0 & 179.6 & 177.6 & 3.20 & 4.52 & 5.50 & 7.36 & 7.49 & 0.20 & 0.47 \\
$A_{a} v g$ & 37.8 & 108.5 & 155.5 & 146.4 & 2.86 & 3.83 & 5.61 & 7.19 & 7.71 & 0.18 & 0.45 \\
$\mathrm{SD}$ & 3.9 & 19.0 & 27.4 & 36.9 & 0.30 & 0.68 & 0.86 & 1.42 & 2.13 & 0.02 & 0.09 \\
$\mathrm{~B} 1$ & 35.5 & 117.2 & 167.4 & 162.0 & 3.30 & 4.56 & 6.04 & 7.40 & 7.50 & 0.21 & 0.47 \\
$\mathrm{~B} 2$ & 26.9 & 91.5 & 130.7 & 129.3 & 3.40 & 4.80 & 10.21 & 12.01 & 12.01 & 0.21 & 0.76 \\
$\mathrm{~B} 3$ & 34.6 & 90.0 & 128.6 & 119.5 & 2.60 & 3.45 & 6.21 & 10.20 & 10.41 & 0.16 & 0.64 \\
$B_{a} v g$ & 32.4 & 99.6 & 142.2 & 136.9 & 3.10 & 4.27 & 7.49 & 9.87 & 9.97 & 0.20 & 0.62 \\
$\mathrm{SD}$ & 4.7 & 15.3 & 21.8 & 22.2 & 0.44 & 0.72 & 2.36 & 2.32 & 2.29 & 0.03 & 0.15 \\
$\mathrm{C} 1$ & 33.7 & 104.1 & 148.7 & 126.9 & 3.09 & 3.68 & 10.19 & 12.23 & 13.00 & 0.20 & 0.77 \\
$\mathrm{C} 2$ & 28.9 & 92.1 & 131.3 & 116.3 & 3.19 & 4.00 & 5.07 & 10.70 & 13.59 & 0.20 & 0.68 \\
$\mathrm{C} 3$ & 40.6 & 95.5 & 136.4 & 110.5 & 2.35 & 2.93 & 6.28 & 10.00 & 14.47 & 0.15 & 0.63 \\
$C_{a} v g$ & 34.4 & 97.2 & 138.8 & 117.9 & 2.88 & 3.54 & 7.18 & 10.98 & 13.69 & 0.18 & 0.69 \\
$\mathrm{SD}$ & 5.9 & 6.2 & 8.9 & 8.3 & 0.46 & 0.55 & 2.67 & 1.14 & 0.74 & 0.03 & 0.07 \\
$\mathrm{D}$ & 30.0 & 56.1 & 80.2 & 79.8 & 1.90 & 2.68 & 4.45 & 4.99 & 5.11 & 0.12 & 0.32 \\
\hline
\end{tabular}

The measured maximum base shear, $V_{\max }$, did not depend on the connection type (variation within $10 \%$ ), though they occurred at significantly different drifts and were smallest for Group A and biggest for Group C specimens. The maximum base shear of the Group D specimen was significantly lower and occurred at much smaller drifts than that of the confined wall specimens. The specimen behaved as a fragile wall with no ductility. Its maximum base shear was about $60 \%$ and the ultimate story drift about $50 \%$ of that of the specimens in Group B.

Tie-columns contributed to the increase of the wall's stiffness, strength and ductility. The ductile behaviour of the specimens depended on the connection details and increased from Group A to B to C.

\subsection{Lateral stiffness}

The correlation of the observed damage grades with drifts, normalized lateral resistance force, $\mathrm{V} / \mathrm{V}_{\max }$, and normalized secant stiffness, $\mathrm{K} / \mathrm{K}_{0}$ where $\mathrm{K}_{0}$ is the initial stiffness, is

Table 5 Observed damage grades with drift, normalized $\mathrm{V}$ and $\mathrm{K}$ for all specimens

\begin{tabular}{|c|c|c|c|c|c|c|c|c|c|}
\hline \multirow[t]{2}{*}{ Group } & \multicolumn{3}{|c|}{ Slight damage Grade 1} & \multicolumn{3}{|c|}{ Moderate damage Grade 2} & \multicolumn{3}{|c|}{ Heavy damage Grade 3 \& 4} \\
\hline & $\mathrm{dr}(\%)$ & $\mathrm{V} / \mathrm{V}_{\max }$ & $\mathrm{K} / \mathrm{K}_{\mathrm{O}}$ & $\operatorname{dr}(\%)$ & $\mathrm{V} / \mathrm{V}_{\max }$ & $\mathrm{K} / \mathrm{K}_{\mathrm{O}}$ & $\operatorname{dr}(\%)$ & $\mathrm{V} / \mathrm{V}_{\max }$ & $\mathrm{K} / \mathrm{K}_{\mathrm{O}}$ \\
\hline $\mathrm{A}_{\mathrm{avg}}$ & 0.18 & 0.60 & 0.84 & 0.35 & 0.98 & 0.63 & 0.48 & 0.77 & 0.33 \\
\hline $\mathrm{B}_{\text {avg }}$ & 0.19 & 0.51 & 0.78 & 0.47 & 1.00 & 0.48 & 0.63 & 0.78 & 0.41 \\
\hline $\mathrm{C}_{\mathrm{avg}}$ & 0.17 & 0.60 & 0.77 & 0.45 & 1.00 & 0.48 & 0.86 & 0.53 & 0.36 \\
\hline $\mathrm{D}$ & 0.16 & 0.87 & 0.90 & 0.28 & 1.00 & 0.56 & 0.32 & 0.70 & - \\
\hline
\end{tabular}



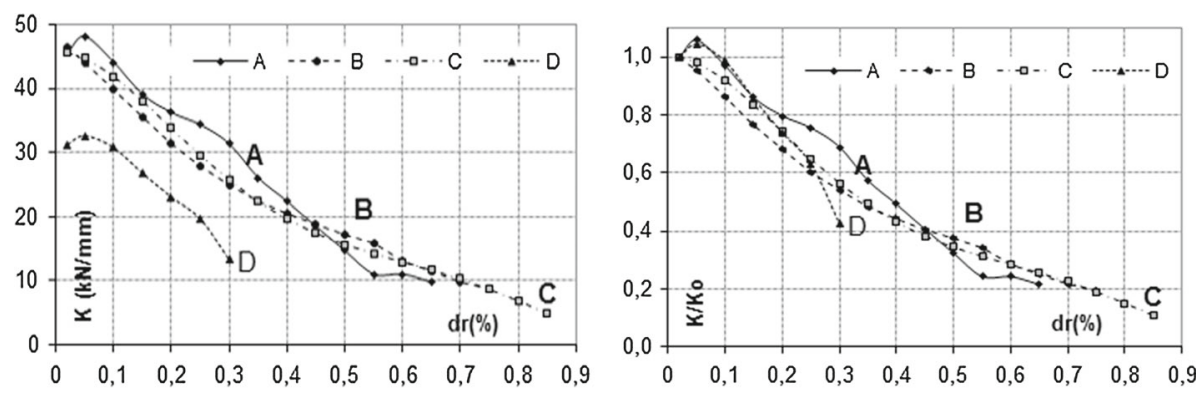

Fig. 11 Deterioration of the secant stiffness (left) and normalized to the initial stiffness $\left(\mathrm{K} / \mathrm{K}_{0}\right.$ right) for the specimens A2, B2, C3 and D

presented in Table 5. Slight damage occurred at drifts of $0.16-0.18 \%$ for all the specimens. The occurrence of moderate and heavy damage grades, as well as the failure type (brittle or ductile) depended on the connection type. Proper confinement improved ductile behaviour and allowed bigger nonlinear drifts.

As can be observed from Tables 4, 5 and Fig. 11, the initial stiffness and average elastic stiffness of all three confined wall types (Groups A, B and C) were almost the same and were $10-26 \%$ higher than in the masonry wall (Group D).

The deterioration of the secant lateral stiffness, for all the wall specimens, was very similar and almost linear up to the collapse. Slight damage in all the specimens occurred at a drift of about $0.18 \%$. Drifts at which moderate and heavy damage occurred depended on the confinement and the connection type, as well as the remaining lateral load carrying capacity. The behaviour of the specimens with a connection was better than when there was no connection.

\subsection{Slippage at the masonry-tie-column interface}

The connection type at the masonry-tie-column interface had an important effect on the development of cracks, their number and distribution, and on the overall wall behaviour. In the Group A specimens an early separation between the wall and the tie-column was observed. After the initial cracking, the separation between the wall and column-ties, the specimens behaved like masonry infilled-frames. The provision of a toothed (Group B) or dowel connection (Group C) prevented separation between the tie-column and the masonry wall and enabled their composite behaviour to go further into the nonlinear range. Relative slippage between the wall and tie-column $(\varepsilon)$ was measured by strain-gauges and the measured values are presented with regard to the measured horizontal displacement (d) and drift in Fig. 12. Slippage along the masonry-column tie interface in the Group A specimens started prior to the wall cracking at drifts of about $0.05-0.1 \%$. In the Group B and $\mathrm{C}$ specimens
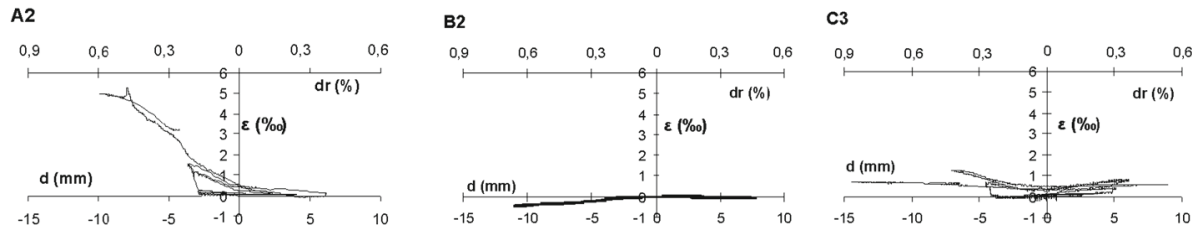

Fig. 12 Slippage between the masonry wall and tie-column for three different connection types 
Table 6 Measured lateral force, average shear stress and characteristic shear stress at the interface

\begin{tabular}{|c|c|c|c|c|c|c|}
\hline \multirow[t]{2}{*}{ Specimen } & \multicolumn{3}{|c|}{$\mathrm{V}_{\mathrm{el}}(\mathrm{kN})$} & \multicolumn{3}{|c|}{$\mathrm{V}_{\max }(\mathrm{kN})$} \\
\hline & $\mathrm{A}_{\mathrm{avg}}$ & $\mathrm{B}_{\text {avg }}$ & $\mathrm{C}_{\text {avg }}$ & $\mathrm{A}_{\mathrm{avg}}$ & $\mathrm{B}_{\text {avg }}$ & $\mathrm{C}_{\mathrm{avg}}$ \\
\hline $\mathrm{V}(\mathrm{kN})$ & 109 & 100 & 97 & 155 & 142 & 139 \\
\hline$\tau_{\mathrm{avg}}=\mathrm{V} /\left(\mathrm{l}_{0} \cdot \mathrm{t}\right) \quad\left(\mathrm{N} / \mathrm{mm}^{2}\right)$ & 0.49 & 0.45 & 0.44 & 0.69 & 0.64 & 0.63 \\
\hline $\mathrm{f}_{\mathrm{vk}}=\mathrm{f}_{\mathrm{vk} 0}+\mu \cdot \sigma_{0} \quad\left(\mathrm{~N} / \mathrm{mm}^{2}\right)$ & 0.44 & 0.44 & 0.44 & 0.62 & 0.62 & 0.62 \\
\hline
\end{tabular}

slippage remained below $1 \%$. For group B specimens the slippage line moved to the concrete tooth ends (increase of the effective column area). Group C specimens had some slippage along the interface line, but once this had started, further increase was controlled by using dowels.

Measured lateral forces $\left(\mathrm{V}_{\mathrm{el}}\right.$ and $\left.\mathrm{V}_{\max }\right)$, average shear stress that occurred at the masonrycolumn tie interface $\left(\tau_{\mathrm{avg}}\right)$, and characteristic shear stress of the masonry wall $\left(\mathrm{f}_{\mathrm{vk}}\right)$ are given in Table 6.

By comparing the calculated average shear stress at the wall-beam interface and characteristic shear stress in the masonry wall (Table 6), the following can be concluded: (a) Cracking force, $\mathrm{V}_{\mathrm{el}}$, occurred when the average shear stress reached the characteristic shear stress of the masonry (by taking into account only cohesion) and (b) the maximum shear force, $\mathrm{V}_{\max }$, occurred when the average shear stress was somewhat higher than the characteristic shear stress of masonry. An improvement of the shear load carrying capacity could be obtained by connecting the beam and the wall.

\subsection{Evaluation of the behaviour factor}

For all the primary curves obtained of all the specimens in a particular group, the average curves were obtained using the Nedler-Mead simplex algorithm (MATLAB R2013b). The goal was to fit the function with two linear parameters and two nonlinear parameters, using the following expression:

$$
V=C_{1} \cdot e^{\left(-\lambda_{1} d\right)}+C_{2} \cdot e^{\left(-\lambda_{2} d\right)} .
$$

The output functions, which represent the average resistance envelope curves for all the specimens, are plotted in Fig. 13a-c.

The obtained average (representative) resistance envelope curves of all the specimen groups were then simplified using bilinear curves based on the method developed by Tomaževič (1999). Both loading cycles, positive and negative, were considered in order to evaluate the maximum lateral force and its degradation.

The representative resistance envelope curves and their bilinear idealizations for all model types are presented in Fig. 14, with their characteristic values given in Table 7.

The presence of the tie-column around the masonry wall enabled the system to enter the nonlinear range. The provision of the additional connection between the reinforced concrete vertical ties and the masonry wall allowed for a greater horizontal displacement of the confined-wall before its collapse (increased ductility). The improved connection brought an increase in the ultimate ductility factor $\left(\mu_{u}=d_{u} / d_{e l}\right)$ of about $10 \%$ and in the ultimate drift of about $30 \%$.

The base values of the behaviour factor, $q^{*}$, for the investigated wall groups, were calculated by an approximate Eq. (8) as suggested in Tomaževič and Weiss (2010). This equation 


\section{(a)}

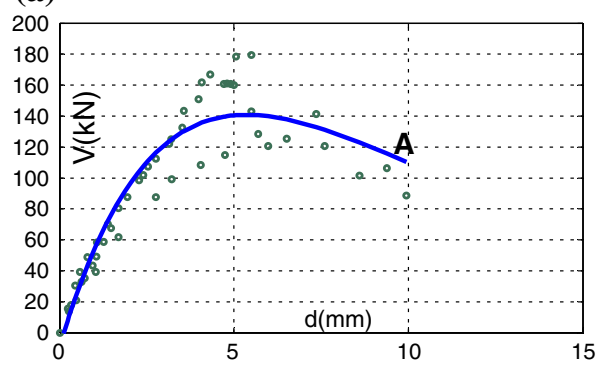

(b)

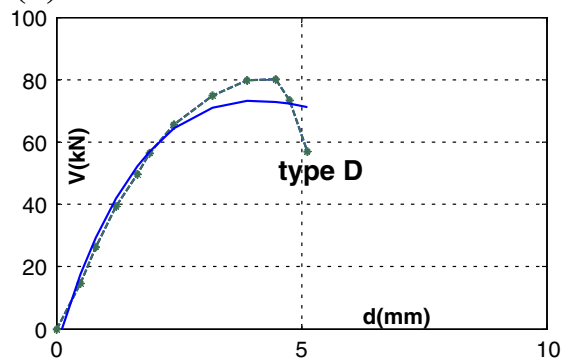

(c)

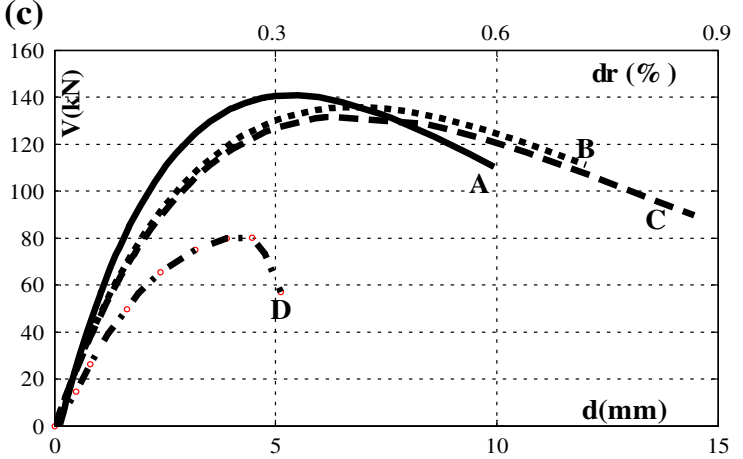

Fig. 13 a Fitted curve for the specimens in Group A. b Fitted curve for the specimens in Group D. c Fitted curves for all test wall groups (A-D)
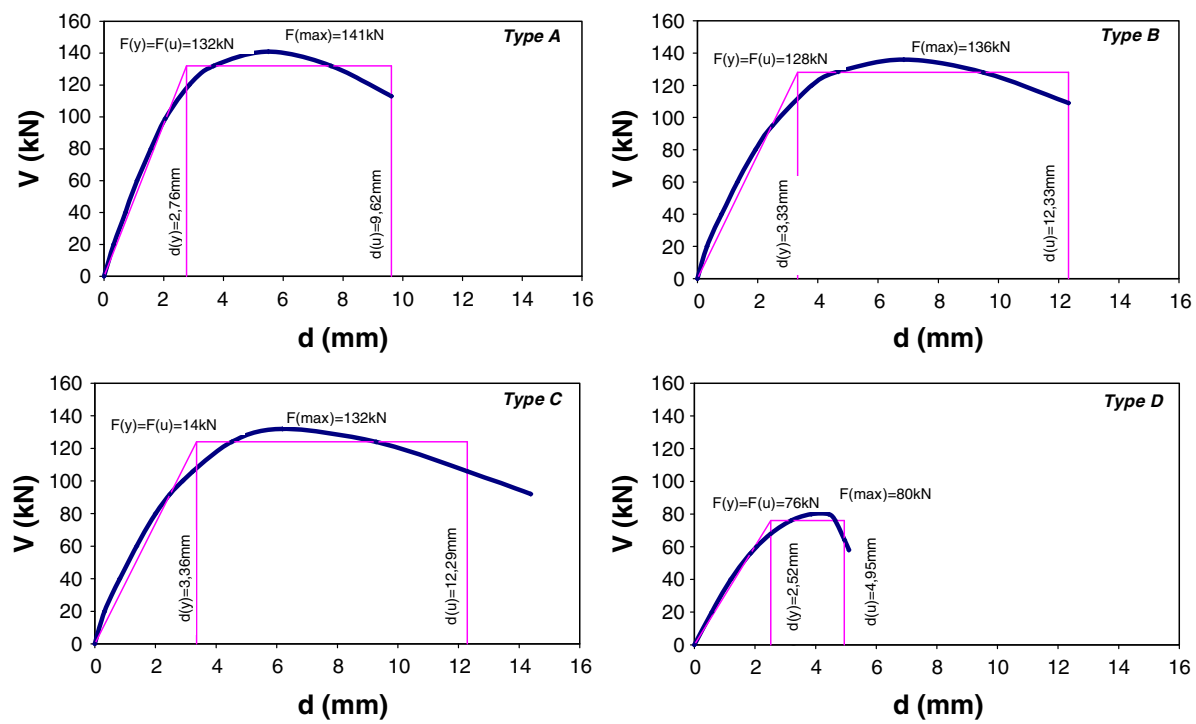

Fig. 14 Fitted average primary curves and their bilinear idealization (Groups A-D) 
Table 7 Evaluated parameters of the averaged resistance envelope curves

\begin{tabular}{lllllllllll}
\hline Specimen & $\begin{array}{l}\mathrm{K}_{\mathrm{el}} \\
(\mathrm{kN} / \mathrm{mm})\end{array}$ & $\begin{array}{l}\mathrm{V}_{\mathrm{el}} \\
(\mathrm{kN})\end{array}$ & $\begin{array}{l}\mathrm{V}_{\mathrm{u}} \\
(\mathrm{kN})\end{array}$ & $\begin{array}{l}\mathrm{d}_{\mathrm{el}} \\
(\mathrm{mm})\end{array}$ & $\begin{array}{l}\mathrm{d}_{\mathrm{y}} \\
(\mathrm{mm})\end{array}$ & $\begin{array}{l}\mathrm{d}_{\mathrm{max}} \\
(\mathrm{mm})\end{array}$ & $\begin{array}{l}\mathrm{d}_{\mathrm{u}} \\
(\mathrm{mm})\end{array}$ & $\begin{array}{l}\text { Crack } \\
\mathrm{drift} \\
\mathrm{dr}_{\mathrm{e}} \%\end{array}$ & $\begin{array}{l}\text { Ultimate } \\
\mathrm{drift} \\
\mathrm{dr}_{\mathrm{u}}(\%)\end{array}$ & $\begin{array}{l}\text { Ultimate } \\
\text { ductility } \\
\mu_{\mathrm{u}}=\mathrm{d}_{\mathrm{u}} / \mathrm{d}_{\mathrm{y}}\end{array}$ \\
\hline $\mathrm{A}$ & 48.3 & 99 & 132 & 2.05 & 2.76 & 9.94 & 9.62 & 0.12 & 0.58 & 3.49 \\
$\mathrm{~B}$ & 38.2 & 95 & 128 & 2.49 & 3.33 & 12.33 & 12.33 & 0.15 & 0.75 & 3.70 \\
$\mathrm{C}$ & 37.2 & 92 & 124 & 2.48 & 3.36 & 14.47 & 12.29 & 0.15 & 0.74 & 3.66 \\
$\mathrm{D}$ & 30.2 & 56 & 76 & 1.86 & 2.52 & 5.11 & 4.95 & 0.11 & 0.30 & 1.96 \\
\hline
\end{tabular}

Table 8 Behaviour factor $q$

\begin{tabular}{llllll}
\hline & $\mathrm{d}_{\mathrm{u}} / \mathrm{h}(\%)$ & $\mu=\mathrm{d}_{\mathrm{u}} / \mathrm{d}_{\mathrm{y}}$ & $\mathrm{V}_{\mathrm{u}} / \mathrm{V}_{\mathrm{el}}$ & $\mathrm{q}^{*}$ & $\mathrm{q}=\mathrm{q}^{*}\left(\mathrm{~V}_{\mathrm{u}} / \mathrm{V}_{\mathrm{el}}\right)$ \\
\hline $\mathrm{A}$ & 0.58 & 3.486 & 1.333 & 2.444 & 3.258 \\
$\mathrm{~B}$ & 0.75 & 3.700 & 1.347 & 2.530 & 3.409 \\
$\mathrm{C}$ & 0.74 & 3.660 & 1.348 & 2.514 & 3.388 \\
$\mathrm{D}$ & 0.30 & 1.962 & 1.357 & 1.710 & 2.321 \\
\hline
\end{tabular}

neglects the soil-structure interaction and equalizes the linear and nonlinear system energy:

$$
q^{*}=\sqrt{\left(2 \mu_{s}-1\right)}
$$

The calculated ductility values and behaviour factors are presented in Table 8 .

The calculated behaviour factors indicate the importance of the proper detailing of the tie-column-masonry interface. They were smaller for those specimens without a connection (A) and higher for those with a connection (B and C). All the behaviour factors, $q^{*}$, values fell within the behaviour range prescribed in Eurocode 8 (unreinforced masonry $q=1.5-2.5$ and confined masonry $q=2.0-3.0$ ).

Nevertheless, and based on results obtained in this and other similar experiments, it is indicated that the behaviour factor to be used in linear analysis may have been redefined through the introduction of the over strength ratio $V_{u} / V_{e l}$ (Morandi 2006). In our case, a $30 \%$ increase of the basic behaviour factor has been found for all the specimen types, indicating the possibility of reducing the design forces for linear elastic analysis with respect to the values traditionally used in the seismic codes for the design of masonry buildings. However, it is important to note that it is necessary to strictly follow construction/geometric rules and conditions.

\subsection{Comparison of the analytical and experimental results}

Few attempts have been made to analytically predict the seismic behaviour of confined masonry walls. We compared three different analytical approaches to predict the maximum shear capacity of tested confined masonry walls expressed as the sum of the masonry wall

Fig. 15 Cross-section of the confined masonry wall

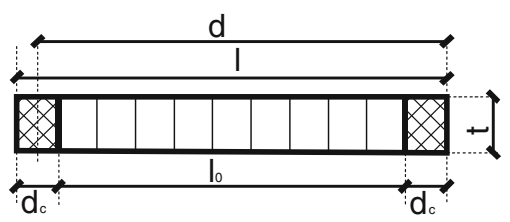


shear and the shear resistance supported by the tie-columns (Fig. 15). These include current Eurocodes (EC2, EC6 and EC8), the expression proposed by Tomaževič (1999) and the experimental expression for confined masonry walls developed from tests of full-scale experiments by Flores and Alcocer (1996), with experimentally determined material values.

In the Eurocodes, when calculating the shear resistance, the rules for unreinforced masonry walls consider the length of the masonry element $\left(l_{0}\right)$ and the contribution of the compressed confining element $\left(\mathrm{d}_{\mathrm{c}}\right)$ was taken into account. Compression stress perpendicular to shear is taken as $\sigma_{0}=0.48 \mathrm{MPa}$. The calculated shear resistance does not depend on the type of connection between the masonry and tie-columns.

$$
V_{R}=V_{R(1)}+V_{R(2)}
$$

The masonry resistance (according to the Eurocode 6 and Table 2) is:

$$
V_{R(1)}<\left\{\begin{array}{l}
\left(f_{v k o}+\mu \cdot \sigma_{o}\right) \cdot t \cdot l_{o}=(0.44+0.291 \cdot 0.48) \cdot 1.157 \cdot 190=127.4 \mathrm{kN} \\
0.065 \cdot f_{b} \cdot t \cdot l_{o}=0.065 \cdot 17 \cdot 190 \cdot 1.157=242.9 \mathrm{kN}
\end{array}\right\}
$$

and the contribution of the tie-columns (Eurocode 2) is:

$$
\left.\begin{array}{l}
V_{R(2)}=\left(v_{\min }+0.15 \cdot \sigma_{0}\right) \cdot t \cdot d_{c 1}=27.4 \mathrm{kN} \\
v_{\min }=0.035 \cdot\left(1+\sqrt{\frac{200}{d_{c 1}}}\right)^{\frac{3}{2}} \cdot \sqrt{f_{c k}}
\end{array}\right\}
$$

where $d_{c 1}=$ effective depth of a cross section. The total shear resistance of the wall is:

$$
V_{R}=127.4+27.4=154.8 \mathrm{kN}
$$

According to the expression suggested by Tomaževič (1999), the total shear resistance of the wall is obtained as the sum of the masonry resistance and the dowel action of the reinforcing bars:

$$
\begin{aligned}
V_{R d}= & \frac{f_{t} \cdot l_{o} \cdot t}{c_{1} \cdot b}\left[1+\sqrt{c_{1}^{2}\left(1+\frac{\sigma_{o}}{f_{t}}\right)+1}\right]+n \cdot 0.806 \cdot \phi^{2} \sqrt{f_{c k} \cdot f_{y k}} \\
= & \frac{0.22 \cdot 1.157 \cdot 190}{2.20 \cdot 1.15}\left[1+\sqrt{2.20^{2}\left(1+\frac{0.48}{0.22}\right)+1}\right] \\
& +8 \cdot 0.806 \cdot 8^{2} \sqrt{0.85 \times 36.8 \cdot 594}=96.7+56.2=152.9 \mathrm{kN}
\end{aligned}
$$

where $c_{1}=2 \alpha b l_{0} / h_{0}$ is the interaction coefficient, which takes into account the distribution of the interaction forces $(\alpha=1.25)$, the distribution of shear stresses along the cross-section of the masonry $(b=h / l=1.15), n$ is the number of vertical reinforcement bars in compressed tie-column and $\phi$ is the bar diameter.

Flores and Alcocer (1996) have, on the basis of experimental results, suggested a tri-linear force-deformation curve for the confined masonry wall. The characteristic points on the curve (Fig. 16) are calculated from the wall geometry and material properties as:

$$
\begin{aligned}
& V_{c r}=0.5 \cdot f_{v k o} \cdot l \cdot t+0.3 \cdot P=0.5 \cdot 0.44 \cdot 1.437 \cdot 190+0.3 \cdot 133=99.9 \mathrm{kN} \\
& V_{\text {max }}=1.25 \cdot V_{c r}=1.25 \times 99.9=125 \mathrm{kN} \text { by dr } \mathrm{V}_{\max }=0.3 \% \\
& \text { and } V_{u}=1.12 \cdot V_{c r}=1.12 \times 99.9=112.0 \mathrm{kN} \text { by dr } \mathrm{Vu}=0.5 \%
\end{aligned}
$$




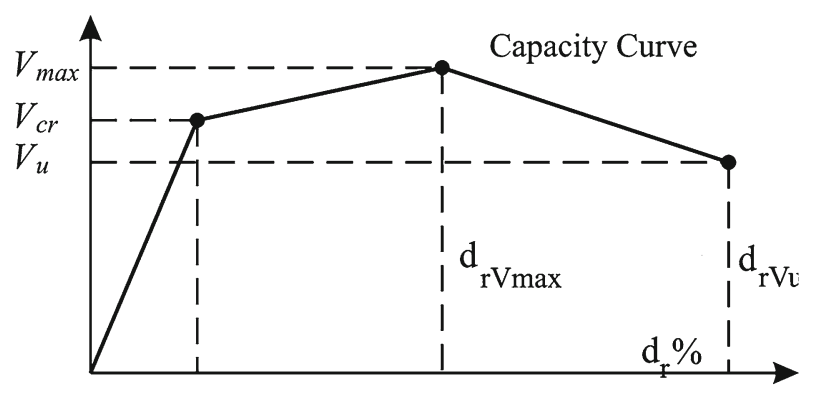

Fig. 16 Primary curve for confined masonry walls (Flores and Alcocer 1996)

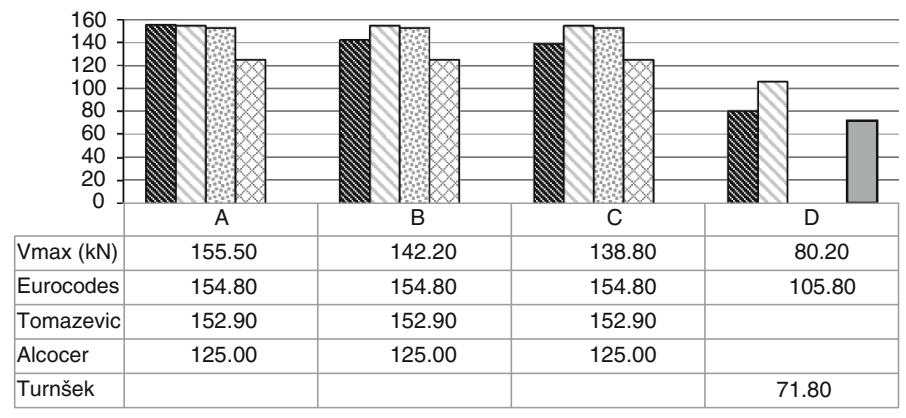

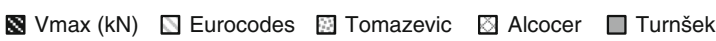

Fig. 17 Calculated and experimental lateral shear resistance of the tested specimens

The shear resistance of the unreinforced masonry wall in Group D is calculated according to the Eurocode 6 as:

$$
V_{R}=\frac{\sigma_{0} \cdot l^{2} \cdot t}{h}\left(1-\frac{\sigma_{0}}{3 \cdot f_{k}}\right)=\frac{0.48 \times 1,437^{2} \cdot 0.190}{1,650}\left(1-\frac{0.48}{3 \times 2.2}\right)=105.8 \mathrm{kN}
$$

and according to the expression suggested by Turnšek and Čačović (1971)

$$
\left.\begin{array}{l}
\tau_{R}=\frac{f_{t}}{1.5} \sqrt{1+\frac{\sigma_{0}}{f_{t}}}=\frac{0,22}{1,5} \sqrt{1+\frac{0.48}{0.22}}=0.262 \mathrm{~N} / \mathrm{mm}^{2} \\
V_{R}=\tau_{R} A_{w}=190 \cdot 1.437 \cdot 0.262=71.8 \mathrm{kN}
\end{array}\right\}
$$

The analytically obtained values of the specimens' shear resistances are compared with the experimental ones in Fig. 17. In the analytical expressions, tie-columns increased the lateral shear resistance of the masonry wall by about $30 \%$, while in the experiments it was about $50 \%$. The total shear resistance of the tested confined masonry walls, $\mathrm{V}_{\max }$, calculated by the Eurocodes and by Tomaževič (1999) was close to the experimental values, although they arrived at them by completely different approach. The expressions suggested by Flores and Alcocer (1996) underestimated the maximum shear resistance $\left(\mathrm{V}_{\max }\right)$, but gave a good approximation of the evaluated bilinear shear capacity (Table 7). The latter were also good at determining the appropriate damage drifts. The expression suggested by Turnšek and Čačović (1971) gave a good approximation of an unreinforced masonry wall's capacity in contrast to the one used in Eurocodes that overestimated the specimen's capacity. 


\section{Conclusion}

Nine specimens of one-bay and one-storey, confined masonry walls with three different connection types, between the masonry wall and reinforced concrete tie-columns, were produced at a 1:1.5 scale as practical true models. Three of the specimens had no additional connection except for adhesion (Group A), three had a toothed connection (Group B) and three had a dowel-stirrup connection (Group C). One additional, unconfined and unreinforced, masonry wall model with the same dimensions was produced for comparison (Group D). All the specimens were tested under constant vertical and in-plane cyclic lateral loads. The measured data were analysed and observations were made.

The maximum shear resistance force calculated by the Eurocodes and by Tomaževič (1999) was very close to the measured values, while those calculated by and Flores and Alcocer (1996) underestimated those measured. The latter approach was very close to the evaluated bilinear ultimate shear capacity of the specimens. Flores and Alcocer (1996) gave a very good estimate of the measured responses regarding the force and drift estimates. In the analytical expressions, the contribution of the masonry brick panel and that of the tie-columns to the total shear force was about 70-30\%, respectively. By comparing the results of the unreinforced masonry wall (Group D) and confined masonry wall specimens (Groups A, B and C) it was concluded that the addition of the column ties brought a lateral strength increase of more than $70 \%$, irrespective of the connection type. Thus, we could conclude that the maximum base shear capacity of all the confined masonry wall specimens was bigger than the sum of the shear capacities of the masonry wall and reinforcedconcrete tie-columns, as used in analytical expressions. Confined masonry walls, in all groups, behaved as composite structures up to a drift level of about $0.2 \%$, until which point the structures remained practically elastic. After that drift level, the influence of the connection type on the inelastic wall behaviour was significant. The observed nonlinear behaviour could be further improved by increasing the shear reinforcement in the columns' critical regions.

By comparing the results of the unconfined and confined masonry walls it was observed that confinement increased the stiffness (from 10 to 26\%), lateral load-carrying capacity (from 70 to $90 \%$ ), ductility (from 78 to $88 \%$ ) and the hysteretic energy damping of the masonry walls. Test results indicated that connection type did not influence the intensity of the lateral resistance force and the deterioration of the secant stiffness. In general, the tests results of specimens in Group A showed a somewhat bigger dispersion, whereas groups B and $\mathrm{C}$ had considerable uniformity of results. The maximum shear force estimated in all confined masonry wall specimens was similar and in accordance with the values obtained by the Eurocodes. However, the connection type did influence the failure type, hysteretic energy dissipation, maximum displacement and ductility. The maximum horizontal displacements and hysteretic energy dissipation achieved by the specimens in Group A were lower than those of the Group B and C specimens. Significantly greater slippage between the masonry and tie-columns in the Group A specimens, in comparison to that observed in Groups B and $\mathrm{C}$, was observed. Nevertheless, no clear separation between the wall and tie-columns was observed.

In the Group A specimens, due to a relative lack of bond between the masonry and tiecolumns, the masonry wall acted like a diagonal strut and their failure was controlled by the diagonal tension failure of the wall. The Group B and C specimens acted like shear walls and failed due to a combined diagonal tension failure of the masonry and shear failure of the reinforced-concrete ties. These specimens had the composite behaviour of the masonry wall and concrete ties. An improvement of the connection between the masonry and the tie- 
columns extended the nonlinear deformation range of the resistance envelope curve and so improved the plastic behaviour of the walls. After considerable cracking of the masonry wall, which occurred at the maximum shear force, the contribution of the tie-columns' became noticeable. The confined wall, in spite of cracking, continued to play an important role in resisting external forces.

Based on these results, it is our opinion that masonry walls with tie-columns that are not properly connected (Group A) can be treated as confined masonry walls, also. Taking into account the lower value of the ultimate drift, faster deterioration of the shear load capacity, lower hysteretic energy dissipation capability and greater dispersion of the test results, we recommend that their behaviour factor remain within the range of the values prescribed by the Eurocode 8 . For specimens with properly connected tie-columns and masonry walls, an increase of the codified behaviour factor should be considered for regular structures due to the over-strength ratio.

Acknowledgments The research presented in this paper is a part of the research project "Seismic design of infilled frames", No. 149-1492966-1536, supported by the Ministry of Science, Education and Sports of the Republic of Croatia and its support is gratefully acknowledged.

\section{References}

Costa A (2007) Experimental testing of lateral capacity of masonry piers, an application to seismic assessment of AAC masonry buildings, Universitat degli Studi di Pavia

Eurocode 2: design of concrete structures: part 1-1, General rules for structures, EN 1992-1-1: 2005, CEN, Bruxelles

Eurocode 6: design of masonry structures: part 1-1 and part 2, common rules for reinforced and unreinforced masonry structures, EN 1996-1-1:2005. CEN, Bruxelles

Eurocode 8: design of structures for earthquake resistance, part 1, general rules, seismic actions and rules for buildings, EN 1998-1:2004. CEN, Bruxelles

Flores LE, Alcocer SM (1996) Calculated response of confined masonry structures. In: Proceedings of the 11 WCEE, Paper No. 1830

Frumento S, Megenes G, Morandi P, Calvi GM (2009) Interpretation of experimental shear tests on clay brick masonry walls and evaluation of q-factors for seismic design. IUSS Press, Pavia

Grünthal G (ed.) (1998) European Macroseismic Scale 1998 (EMS-98). Original Edition, Luxembourg 1998: ESC

Harris HG, Sabnis GM (1999) Structural modeling and experimental techniques, 2nd edn. CRC Press LLC, Florida

Marinilli A, Castilla E (2004) Experimental evaluation of confined masonry walls with several confiningcolumns, 13th World conference on earthquake engineering Paper No. 2129, Vancouver, BC

MathWorks (2013) MATLAB. (R2013b) [computer program] The MathWorks Inc

Matošević D, Sigmund V, Zovkić J (2009) Experimental testing of masonry and masonry piers. In: 6th ICCSM Proceedings, CSM, Dubrovnik

Meli R, Brzev S et al. (2011) Seismic design guide for low-rise confined masonry buildings, earthquake engineering research institute, Oakland, CA. www.confinedmasonry.org

Morandi P (2006) Inconsistencies in codified procedures for seismic design of masonry buildings. A dissertation submitted in partial fulfilment of the requirements for the master degree in earthquake engineering, Istituto Universitario Università degli di Studi Superiori Studi di Pavia

San Bartolome A, Quiun D, Mayorca P (2004) Proposal of standard for seismic design of confined masonry buildings. Bulletin of ERS, No 37

Tomaževič M (1999) Earthquake resistant design of masonry buildings. Imperial College Press, London

Tomaževič M, Bosiljkov V, Weiss P (2004) Structural behaviour factor for masonry structures. In: 13th World conference on earthquake engineering, Vancouver

Tomaževič M, Weiss P (2010) Displacement capacity of masonry buildings as a basis for assessment of behaviour factor: an experimental study. Bull Earthq Eng 8(6):1267-1294

Turnšek V, Čačović F (1971) Some experimental results on the strength of brick masonry walls. In: Proceedings of the 2nd international brick masonry conference, Stoke-on-Trent, pp. 149-156 
UNIDO/UNDP, (1984) Volume 5, Repair and strengthening of reinforced concrete, stone and brick-masonry buildings, Building construction under seismic conditions in the Balkan Region, Project Report RER/79/015 World Housing Encyclopedia (2011) EERI \& IAEE. Confined masonry network, seismic design guide for low-rise confined masonry buildings 